\title{
VERTICAL COORDINATION, ANTITRUST LAW, AND INTERNATIONAL TRADE*
}

\author{
STEPHEN F. HAMILTON \\ University of \\ Arizona
}

\author{
and
}

\author{
KYLE STIEGERT \\ Kansas State \\ University
}

\begin{abstract}
This paper demonstrates that vertically aligned private or public organizations are capable of generating strategic trade advantage similar to that acquired through direct government export subsidization. The model considers two forms of vertical coordination that lead to advantageous trade positions in international markets: upstream vertical restraint and downstream equity sharing. Such practices are commonly employed both by state trading agencies and by private firms in nations with lenient antitrust laws. The finding has important implications under new World Trade Organization (WTO) rules intended to reduce government intervention in international transactions. Recent reforms in the WTO favor nations that sanction highly refined vertical linkages between firms, while nations with stringent antitrust legislation have an incentive to negotiate for greater harmonization of international laws.
\end{abstract}

\section{INTRODUCTION}

J ${ }_{\text {LOBALLY traded goods are often produced in vertically structured eco- }}$ nomic sectors in which a final product is developed through a series of transactions between upstream suppliers of inputs and downstream producers, intermediaries, and retailers. In many nations, vertical transactions in a chain of production are arranged through highly coordinated linkages between firms. The celebrated Japanese keiretsu and the less familiar Korean chaebols are examples of industrial structures that involve linked equity interests of vertically aligned corporations. ${ }^{1}$ The success of such vertically co-

* The authors would like to thank James Brander, Yang-Ming Chang, Kala Krishna, Jeffrey Perloff, Roger McEowen, and an anonymous referee for helpful comments.

1 The cross-shareholding feature between vertical stages of keiretsu organizations has been associated with improved product quality, relaxed financial restrictions on new plant investment, greater market penetration, increased incidences of dumping, and reductions in new firm entry and survival. For cross shareholding and product quality, see David Flath, Vertical Integration by Means of Shareholding Interlocks, 7 Int'l J. Indus. Org. 369 (1989). For evidence of relaxed financial restrictions, see Rene Belderdos \& Leo Sleuwaegen, Japanese Firms and the Decision to Invest Abroad: Business Groups and Regional Core Networks, 78 Rev. Econ. \& Stat. 214 (1996). For market penetration and dumping, see Leonard K. Cheng \& Mordechai E. Kreinin, Supplier Preferences and Dumping: An Analysis of Japanese Corporate Groups, 63 S. Econ. J. 51 (1996). For an analysis of de novo firm entry and sur-

[Journal of Law and Economics, vol. XLIII (April 2000)]

(C) 2000 by The University of Chicago. All rights reserved. $0022-2186 / 2000 / 4301-0006 \$ 01.50$ 
ordinated industry structures is widely recognized in international markets. ${ }^{2}$ Another common form of vertical coordination is arranged through government marketing boards, which directly control the internal transfer price between upstream producers and downstream retailing agents. Examples include the single-desk selling systems of state trading enterprises such as the Canadian and Australian Wheat Boards, which typically purchase grain at below-market prices, then reimburse commodity producers with a share of profits in the downstream international markets. This paper examines the strategic trade implications of these and other vertically coordinated industry structures.

The model demonstrates that nations with lenient antitrust standards have a strategic trade advantage in international markets. This result is not driven by returns to scale or by differences in productive efficiency; rather, it is built solely on the benefits derived by downstream firms that employ backward linkages as precommitment mechanisms. ${ }^{3}$ However, unlike the outcome of a government subsidization program, in which the noncooperative Nash equilibrium is characterized by multilateral export promotion and a reduction in the welfare of producing nations, unilateral precommitment outcomes occur when legal restrictions within a rival nation prohibit private mechanisms for vertical control. The implications of the model are thus important both in the formation of antitrust policy and in the negotiation of free-trade agreements. If international restrictions are imposed to reduce government promotion of exports, as currently sanctioned by the World Trade Organization (WTO), unilateral precommitment strategies are still possible up to the limits imposed by national (and international) antitrust laws.

vival, see David D. Li \& Shan Li, A Theory of Corporate Scope and Financial Structure, 51 J. Fin. 691 (1996).

${ }^{2}$ See, for example, Vincent Cable, The New Trade Agenda: Universal Rules amid Cultural Diversity, 72 Int'l Affairs 227 (1996); and David Flath, The Keiretsu Puzzle, 10 J. Japanese \& Int'l Econ. 101 (1996).

${ }^{3}$ In this regard, our model is related to strategic trade models that examine the profitshifting effect of government precommitment for export promotion. See, for example, James A. Brander \& Barbara J. Spencer, Export Subsidies and International Market Share Rivalry, 18 J. Int'l Econ. 83 (1985); Giovanni Maggi, Strategic Trade Policies with Endogenous Mode of Competition, 86 Am. Econ. Rev. 237 (1996); and Kyle Bagwell \& Robert W. Staiger, The Sensitivity of Strategic and Corrective R\&D Policy in Oligopolistic Industries, 36 J. Int'l Econ. 133 (1994). The implications of vertical arrangements for strategic trade policy have been examined by Barbara J. Spencer \& Ronald W. Jones, Vertical Foreclosure and International Trade Policy, 58 Rev. Econ. Stud. 153 (1991); and Barbara J. Spencer \& Ronald W. Jones, Trade and Protection in Vertically Related Markets, 32 J. Int'l Econ. 31 (1992). These latter studies, which analyze importer and exporter policies when an upstream firm supplies inputs to a domestic and/or a foreign final goods producer, consider the role of government as an arbiter in international transactions, and they do not examine the effect of legal and institutional structure on trade outcomes. 
Existing analyses in the international trade literature typically presume that only governments are capable of generating precommitment mechanisms to capture strategic trade benefits. To the best of our knowledge, there has been no analysis of strategic trade incentives in the context of private precommitment mechanisms. The omission is rather surprising given that these methods are well defined in firm-level principal-agent models. ${ }^{4}$ These papers focus on the case in which strategic precommitment is accomplished through delegation within a single institution. Our paper deviates from this framework to consider the case of arm's-length transaction in which the agent signing the contract remains a separate corporate entity. The formal structure is thus similar to that examined in the vertical separation literature, though unique connections are made here between vertical structure, antitrust law, and international trade. ${ }^{5}$ In particular, the present analysis considers the case in which exchange that occurs between firms is subject to review by a national antitrust authority, and, consequently, highly refined vertical linkages may be allowed in some nations while prohibited in others. ${ }^{6}$

Current antitrust standards vary widely across nations. In the United States and in most European Union (E.U.) nations, for example, legislation governing vertically coordinated transactions (hereafter, vertical antitrust law) limits the formation of vertical arrangements such as keiretsu and chaebols and encumbers the development of government-sanctioned export marketing boards. The E.U. has recently worked toward harmonization in a system of minimal merger control regulations and intends to expand harmonization principles to Central European, east European, and Mediterranean nations. However, many other countries, particularly those in developing regions, still lack a sophisticated legal system governing anticompetitive behavior. ${ }^{7}$ Indeed, as Ernst-Ulrich Petersmann notes, the cur-

${ }^{4}$ See, for example, John Vickers, Delegation and the Theory of the Firm, 95 Econ. J. 138 (1985); Chaim Fershtman \& Kenneth L. Judd, Equilibrium Incentives in Oligopoly, 77 Am. Econ. Rev. 927 (1987); Steven D. Sklivas, The Strategic Choice of Managerial Incentives, 18 RAND J. Econ. 452 (1987); and David Reitman, Stock Options and the Strategic Use of Managerial Incentives, 83 Am. Econ. Rev. 513 (1993).

${ }^{5}$ For greater detail on the potential effects of vertical separation, see Y. Joseph Lin, Oligopoly and Vertical Integration: Note, 78 Am. Econ. Rev. 251 (1988); Giacomo Bonanno \& John Vickers, Vertical Separation, 36 J. Indus. Econ. 257 (1988); Anne T. Coughlin \& Birger Wernerfelt, On Credible Delegation by Oligopolists: A Discussion of Distribution Channel Management, 35 Mgmt. Sci. 226 (1989); and Kai-Uwe Kühn, Nonlinear Pricing in Vertically Related Duopolies, 28 RAND J. Econ. 37 (1997).

${ }^{6}$ Direct integration may be possible in some cases, although a proposed merger between upstream and downstream producers is also likely to involve antitrust scrutiny.

7 The movement toward international harmonization of antitrust law is still in its infancy. In 1993, a draft of the international antitrust code (DIAC), which outlines various per se laws and rules of reason on horizontal and vertical restraints, was provided to the WTO. See 
rent degree of antitrust cooperation among nations is "widely regarded as inadequate," and the possibility of an emerging worldwide competition authority "is not a politically realistic short or medium-term option." 8

The body of antitrust law that governs vertical transactions may play an important role in determining the source of comparative advantage along a production chain. Specifically, trade distortions may emerge through asymmetric antitrust legislation as nations that allow highly refined vertical linkages gain comparative advantage in the production of finished goods while nations with stringent antitrust laws acquire comparative advantage in the production of raw materials. Given the fact that downstream industries are typically high-value-added stages of production, the source of comparative advantage in vertically structured sectors is of particular policy concern.

The remainder of the paper is organized as follows: Section II presents a theoretical model of international trade in a vertically structured sector composed of a competitive upstream raw material industry and an oligopolistic downstream final goods market. Section III presents our analysis regarding two primary forms of vertical control: upstream vertical restraint and downstream equity sharing. Section IV discusses implications for policy analysis, and Section V concludes.

\section{The Formal Model}

The model considers a vertically structured sector composed of a competitive upstream raw-material industry and an imperfectly competitive downstream producer of a final good. The raw-material industry in each country produces a homogeneous input at constant marginal cost, $c$, which is sold to a single downstream firm and costlessly transformed via a Leontief technology into homogeneous output of a final good. ${ }^{9}$ The final good is then sold in an international market, composed of a domestic and a foreign firm, which are labeled firms 1 and 2, respectively.

United Nations, The Role of Competition Policy in Economic Reforms in Developing or Other Countries (1993). Ernst-Ulrich Petersmann, International Competition Rules for Governments and for Private Business: A Trade Law Approach for Linking Trade and Competition Rules in the WTO, in Public Policy and Global Technological Integration (Frederick M. Abbott \& David J. Gerber eds. 1997), provides an excellent summary of existing international antitrust law in the WTO.

8 Petersmann, supra note 7 , at 243-44.

9 These restrictions are imposed purely for expositional convenience. With constant marginal cost in the upstream industry, the strategic motive to form contracts is isolated from the incentive of downstream firms to develop backward relations to reduce efficiency loss. For an analysis of such incentives, see Martin K. Perry, Vertical Integration: The Monopsony Case, 68 Am. Econ. Rev. 561 (1978). With Leontief technology in the downstream industry, the model abstracts from issues of input substitutability. Extension of the model to consider more general relationships in either direction would be relatively straightforward. 
Strategic interaction between the firms is modeled as a three-stage game, the timing of which is described as follows. In the first stage, the contract stage, the domestic downstream firm writes an observable and nonrenegotiable contract with one or more of its input suppliers. The contract specifies the wholesale price of the input $w$, the upstream firms share of downstream profits $\alpha$, and/or a fixed transfer $F$. In the second stage, the acceptance stage, the upstream supplier either accepts or rejects the contract. If the contract is rejected, then the domestic firm purchases the input on the spot market at marginal cost $c$. In the third and final stage, the output stage, the domestic and foreign firms compete in an international Cournot-Nash oligopoly.

Such a sequence of events accords well with the contract design of marketing agents in State Trading Enterprises. For example, prior to harvest each year, the Canadian Wheat Board (CWB) announces initial procurement prices for Canadian grains, which are typically set at 75-80 percent of the forecasted international prices. At the end of the marketing season, final payments are made to producers based on proceeds from international sales. Such procurement contracts are legally binding in the short run, although the long-run acceptance of the contracts, and indeed of the institutional structure of the CWB itself, depends critically on the ability of the agency to provide sufficient final payments to compensate producers for their initial losses on below-market sales of grain.

Throughout, we confine attention to a domestic downstream firm that is legally allowed to establish vertical control of the upstream market through the contractual arrangement described above, while the foreign firm operates under the auspices of an antitrust authority that does not allow the formation of procurement contracts. That is, the foreign firm is constrained to purchase inputs in the spot market at marginal cost $c$.

Let $Q$ represent industry output of the final good and denote the downstream inverse demand function as $P(Q)$, which is assumed throughout to be strictly decreasing and twice continuously differentiable. Furthermore, it is assumed that

$$
P^{\prime}(Q)+Q P^{\prime \prime}(Q)<0,
$$

which ensures the existence of equilibrium and implies that outputs are strategic substitutes. ${ }^{10}$

The model is solved using backward induction. Accordingly, the output stage is solved first, followed by the acceptance and contract stages, respectively. If the upstream firm accepts the contract proposed by the domestic

${ }^{10}$ William Novshek, On the Existence of Cournot Equilibrium, 52 Rev. Econ. Stud. 85 (1985). 
downstream firm, then the objective function of the downstream firm in the output stage is

$$
\pi_{1}\left(q_{1}, Q, \alpha, w, F\right)=(1-\alpha)(P(Q)-w) q_{1}-F .
$$

Maximizing (2) with respect to output yields the following necessary condition:

$$
P(Q)+q_{1} P^{\prime}(Q)-w=0 .
$$

The foreign firm's objective function in the output stage is

$$
\pi_{2}\left(q_{2}, Q\right)=(P(Q)-c) q_{2},
$$

which is associated with the first-order condition

$$
P(Q)+q_{2} P^{\prime}(Q)-c=0 .
$$

In the output stage, the level of output per firm and total industry output, which are denoted $q_{i}(w, c)$, where $i=1,2$, and $Q(w, c)$, respectively, are obtained by solving (3) and (4). Totally differentiating these equations yields the ratio of comparative statics associated with the domestic firm's choice of $w$,

$$
\frac{\partial q_{2}(w, c) / \partial w}{\partial q_{1}(w, c) / \partial w}=-\frac{P^{\prime}(Q)+q_{2} P^{\prime \prime}(Q)}{2 P^{\prime}(Q)+q_{2} P^{\prime \prime}(Q)},
$$

which is negative given (1).

In the acceptance stage, the upstream firm is willing to accept the contract proposed by the domestic downstream firm provided it receives a payment no less than its opportunity costs. Given that the upstream industry is perfectly competitive, these opportunity costs can be normalized to zero without loss of generality. As a result, the upstream firm accepts the contract proposed by the downstream firm whenever the following participation constraint is satisfied:

$$
(w-c) q_{1}(w, c)+F+\alpha[P(Q(w, c))-w] q_{1}(w, c) \geq 0 .
$$

In the contract stage, the downstream firm chooses the terms of the contract so as to maximixe profits in (2) subject to the participation constraint (6) and the output stage solutions above. Substituting the output stage solutions into (2) and (6), the contracting problem can be written as

$$
\max _{w, \alpha, F} \pi_{1}(w, \alpha, F)=(1-\alpha)[P(Q(w, c))-w] q_{1}(w, c)-F
$$

subject to

$$
(w-c) q_{1}(w, c)+F+\alpha[P(Q(w, c))-w] q_{1}(w, c) \geq 0 .
$$


Substitution of the constraint results in the following unconstrained problem:

$$
\max _{w} \pi_{1}(w)=[P(Q(w, c))-c] q_{1}(w, c) .
$$

Suppressing some of the output-stage solution notation, differentiation of (7) with respect to $w$ gives the necessary condition for a profit-maximizing contract,

$$
(P(Q)-c) \frac{\partial q_{1}(w, c)}{\partial w}+q_{1} P^{\prime}(Q) \frac{\partial Q(w, c)}{\partial w}=0 .
$$

Next, divide (8) through by $[\partial(w, c)] / \partial w$, substitute $[\partial Q(w, c)] / \partial w=$ $\sum_{i=1,2}\left[\partial q_{i}(w, c)\right] / \partial w$, and then let $\partial q_{2} / \partial q_{1}\left(q_{2}, Q\right)=\left[\partial q_{2}(w, c) / \partial w\right] /\left[\partial q_{1}(w\right.$, $c) / \partial w]$ denote the ratio of comparative statics given in (5). Making use of this expression, if $q_{2}^{*}$ and $Q^{*}$ represent the equilibrium levels of firm 2 output and industry output, respectively, then firm 1's equilibrium level of output, $q_{1}^{*}$, must satisfy

$$
P\left(Q^{*}\right)-c+q_{1}^{*} P^{\prime}\left(Q^{*}\right)\left[1+\frac{\partial q_{2}}{\partial q_{1}}\left(q_{2}^{*}, Q^{*}\right)\right]=0 .
$$

Using expression (4), firm 2's equilibrium level of output satisfies

$$
P\left(Q^{*}\right)-c+q_{2}^{*} P^{\prime}\left(Q^{*}\right)=0 .
$$

The equilibrium levels of output for the domestic and foreign firm are thus obtained by substituting $Q^{*}=q_{1}^{*}+q_{2}^{*}$ into (9) and (10) and solving these two equations simultaneously.

To determine the equilibrium choice of $w$, denoted $w^{*}$, the ouput solution (9) is substituted into (3), which obtains

$$
w^{*}-c=-q_{1}^{*} P^{\prime}\left(Q^{*}\right) \frac{\partial q_{2}}{\partial q_{1}}\left(q_{2}^{*}, Q^{*}\right)<0,
$$

where the inequality holds by (1) and (5). Thus, the optimal contract by the downstream firm specifies that the upstream firm sell inputs at a loss to the downstream firm.

\section{Backward Linkages and Strategic Trade}

This section examines two types of contractual relations: upstream vertical restraint and downstream equity sharing. Each form of vertical control is a special case of the above model. For the case of upstream vertical restraint, the downstream firm compensates the input supplier for selling at a loss by paying a fixed transfer (that is, $\alpha=0$ and $F>0$ ), while, for the 
case of downstream equity sharing, compensation is made with a share of profits (that is, $\alpha>0$ and $F=0$ ). ${ }^{11}$

\section{A. The Case of an Upstream Vertical Restraint}

In many nations, government marketing boards and private firms implement various forms of upstream vertical restraint to directly orchestrate the pricing behavior of upstream suppliers. Such explicit control of prices in affiliated stages of production, whether implemented backward or forward, poses legal challenge in other nations. In the United States, for example, there are actually several related antitrust issues governing vertical relationships. ${ }^{12}$ Most directly, a claim may be made against the downstream firm for imposing a vertical restraint. ${ }^{13}$ In addition, if more than one downstream firm produces in a region of antitrust authority, both upstream and downstream firms may be considered in violation of price discrimination law if the upstream firm does not charge identical prices in transactions with rival downstream producers. ${ }^{14}$ Even in the case of a single upstream firm and a single downstream firm, moreover, a vertical restraint is in violation of U.S. antitrust law if the contractual arrangement is deemed to create an entry barrier. $^{15}$

For the case of upstream vertical restraint, the downstream firm compensates the input supplier for selling at a loss in expression (11) through the

${ }^{11}$ Note that there are also many possible combinations of profit sharing and fixed transfers that the downstream firm can use to compensate the upstream firm for selling inputs at a loss to the downstream firm. For example, it is possible to combine these two forms of vertical control in various systems of "impure" equity sharing that involve both a fixed revenue transfer and a share of downstream profits.

12 Jeffrey M. Perloff, Daniel L. Rubinfeld, \& Paul Ruud, Antitrust Settlements and Trial Outcomes, 78 Rev. Econ. \& Stat. 401 (1996), identifies 13 antitrust categories based on U.S. settlement and trial outcomes, several of which generally apply.

${ }_{13}$ Monsanto Co. v. Spray-Rite Service Corp., 465 U.S. 752 (1984); Group Life \& Health Insurance Co. v. Royal Drug Co., 440 U.S. 205 (1979); and Albrecht v. Herald Co., 390 U.S. 145 (1968).

${ }^{14}$ The U.S. courts have held downstream firms culpable for receiving the benefits of discriminatory prices in Federal Trade Commission v. Fred Meyer, Inc., 390 U.S. 341 (1968); and Boise Cascade Corp., No. 9133 (F.T.C., November 1, 1990). In the case of vertical restraints, a single firm contracting for a lower price with an upstream producer would not be considered to have the requisite anticompetitive effect on market power under Section 2 of the Sherman Act unless there is also evidence of monopsony power in the industry. See Medical Arts Pharmacy of Stamford, Inc. v. Blue Cross \& Blue Shield of Connecticut, 518 F. Supp. 1100 (D. Conn. 1981), aff'd, 675 F.2d 502 (2d Cir. 1982).

${ }^{15}$ See William P. Bivins Jr., Texaco v. Hasbrouck: The Supreme Court Reviews Functional Discounts under the Robinson-Patman Act, 36 Antitrust Bull. 413 (1991). 
payment of a fixed transfer, $F$. If $\alpha$ is set equal to zero in the above model, then the participation constraint (6) implies that the optimal payment (that is, the minimum sufficient payment) is given by

$$
F^{*}=\left(c-w^{*}\right) q_{1}^{*} .
$$

Through use of (12), the downstream firm is thus able to use the upstream vertical restraint as a mechanism to create a credible output expansion in the final goods market by restructuring production costs between fixed and marginal cost components. The upstream price restraint, which stipulates a below-marginal-cost input price in the domestic upstream market, thereby precommits the domestic firm to an ex post beneficial output expansion in the downstream international market.

\section{B. The Case of Downstream Equity Sharing}

It is well known that vertical control can be arranged in various institutional forms. In conventional circumstances of retail vertical restraint (for example, resale price maintenance), a producer can solve various retail externality problems, often equivalently, through franchising and exclusive territories, through quantity forcing, and through direct integration of retail units. Similarly, the strategic advantage gained by employment of an upstream vertical restraint, as outlined above, may be accomplished with a backward contract that relies on equity sharing in the downstream industry.

As David Flath demonstrates, vertically related Cournot-Nash oligopolies produce a greater level of output when upstream firms own equity shares of downstream firms. ${ }^{16}$ However, linked equity interests violate antitrust law in certain nations. For example, the U.S. Supreme Court ruled against DuPont holding a stock interest in General Motors on the basis that DuPont's ownership share allowed it to sell paint and fabric on grounds other than "competitive merit." 17 Similar vertical antitrust laws regarding equity-sharing arrangements also exist among most E.U. members, while other nations such as Japan, Korea, China, and Brazil allow linked equity interests in vertically structured sectors. ${ }^{18}$

Under a system of downstream equity sharing, the downstream firm compensates the upstream firm with a share of profits in the international mar-

${ }^{16}$ Flath, supra note 2.

${ }^{17}$ United States v. E. I. du Pont de Nemours \& Co., 351 U.S. 377 (1956).

${ }^{18}$ For a comparative assessment of U.S. and Japanese antitrust law, see Hiroshi Iyori \& Akinori Uesugi, The Antimonopoly Laws and Policies of Japan (1994). 
ket. Making the restriction $F=0$ in the above model, the participation constraint (6) implies that the minimum size of the equity share is equal to

$$
\alpha^{*}=\frac{c-w^{*}}{P\left(Q^{*}\right)-w^{*}} \text {. }
$$

Substituting (3) and (11) into (13) results in the following:

$$
\alpha^{*}=-\frac{\partial q_{2}}{\partial q_{1}}\left(q_{2}^{*}, Q^{*}\right)
$$

Equations (1), (5), and (10) together ensure that $\alpha^{*}$ lies between zero and one, which implies that the contract can be interpreted as a profit-sharing contract. ${ }^{19}$

The idea that equity sharing can be used as a strategic mechanism in a competitive upstream industry is related to the incentive for delegation within a single institution. As observed by Chaim Fershtman and Kenneth Judd, the owner of a firm has an incentive to distort his or her manager's incentives (for instance, toward sales instead of profit maximization) whenever the reaction of the owner's competitors is beneficial. ${ }^{20}$ Our analysis reveals a similar result here in the case of arm's-length transaction. A vertical contract that transfers a share of downstream equity to the upstream firm provides a method of precommitment that is equivalent to that acquired through the use of an upstream price restraint. The use of vertical contracts to acquire strategic advantage, therefore, is quite robust to alternative methods of compensation between upstream and downstream firms.

\section{ImPlications for Policy Analysis}

The control of upstream production decisions, either through upstream vertical restraint or through downstream equity sharing, results in an outcome similar to that acquired through direct government export promotion. However, unlike the case of export subsidization, in which the best response strategy of a foreign government is a countervailing subsidy, unilateral outcomes are maintained when vertical antitrust law is not sufficiently harmonized across nations or when certain nations employ government marketing agents while others do not. The enforcement of vertical antitrust

19 In a context of labor contracts, Bernard Bensaïd \& Robert J. Gary-Bobo, Negotiation of Profit-Sharing Contracts in Industry, 35 Eur. Econ. Rev. 1069 (1991), derives a similar result for the symmetric case of $n$ firms under conditions of linear demand. The derivation provided here is more general and can readily be extended to consider the symmetric $n$ firm case.

${ }^{20}$ Fershtman \& Judd, supra note 4. 
laws within a nation, in fact, may provide the very mechanism by which firms in a rival nation are able to acquire and maintain strategic advantage in the international market. Irregularities between downstream firms in the ability to establish backward linkages can thus create asymmetry between nations in the balance of trade.

Differences between nations in antitrust laws may also affect comparative advantage in vertically structured sectors. If downstream firms capitalize on legal opportunities for upstream vertical control, then nations with lenient vertical antitrust laws may gain comparative advantage in the production of finished products. Conversely, a trade competitor with restrictive vertical antitrust laws may have comparative advantage in the production of raw commodities and truncate the chain of vertical production at the upstream level. The source of comparative advantage in vertically structured sectors is an important policy concern for governments that wish to maintain domestic downstream industries and attract foreign investment in high-value-added stages of production. An implication of this paper is that enforcing restrictive vertical antitrust laws at the national level may be inconsistent with such objectives.

Another implication of the model is that a uniform relaxation of antitrust laws across nations generates a procompetitive effect. When contractual relations are allowed to develop in both domestic and foreign nations, a noncooperative Nash equilibrium arises in which the formation of a vertical contract is a best-response strategy to contracting by a rival firm. Thus, vertical coordination is likely to occur multilaterally in environments with relaxed vertical antitrust legislation, even though such actions reduce aggregate profit in the downstream industry. In the present context, the procompetitive effect of such multilateral contractual relations would lead to an enhancement of global welfare, as the formation of highly refined linkages between firms expands global production, reduces the price of the final good, and thereby increases social surplus.

\section{Concluding Comments}

The existing literature on strategic trade theory focuses primarily on the role of government intervention in redirecting firm-level behavior to welfare-improving trade equilibria. In this paper, we have explored a much different characterization of strategic trade in which the only role of a nation's regulator is to determine the legal boundaries that govern firm behavior through the establishment of national antitrust policy.

The paper has demonstrated the ability of downstream firms or government marketing boards to employ backward linkages with affiliated upstream producers to generate strategic advantage in export markets. Alter- 
native systems of upstream price restraints and downstream equity sharing were shown to be consistent with profit maximization in each stage of production. In the context of nonharmonized vertical antitrust legislation, the paper has demonstrated that backward linkages improve the strategic position of firms that operate in nations without legal impediment to vertical control. Thus, antitrust laws, which have ironically been shown to decrease welfare in many different contexts, also adversely affect domestic profitability and reduce export volume in international markets. ${ }^{21}$

Future international trade negotiations are likely to focus on ways to further limit government intrusion in global markets. An important implication of the paper is that nations with restrictive vertical antitrust legislation have an incentive to establish greater harmonization of international laws. Vertical antitrust legislation is strategically disadvantageous to a nation in that it limits the establishment of backward linkages with upstream producers as precommitment mechanisms in export markets.

Previous studies have suggested that, eventually, global trade may fall under a general set of harmonized competition policies. ${ }^{22}$ In order for this to occur, a greater understanding is needed about the importance of antitrust harmonization. The findings in this paper address these questions for the subset of antitrust law pertaining to vertically structured economic sectors. An implication of the paper is that nations with stringent regulations governing vertical transactions have an incentive to negotiate for further harmonization of international antitrust laws.

\section{BIBLIOGRAPHY}

Bagwell, Kyle, and Staiger, Robert W. "The Sensitivity of Strategic and Corrective R\&D Policy in Oligopolistic Industries." Journal of International Economics 36 (1994): 133-50.

Belderdos, Rene, and Sleuwaegen, Leo. "Japanese Firms and the Decision to Invest Abroad: Business Groups and Regional Core Networks."' Review of Economics and Statistics 78 (1996): 214-20.

Bensaïd, Bernard, and Gary-Bobo, Robert. "Negotiation of Profit-Sharing Contracts in Industry." European Economic Review 35 (1991): 1069-85.

Bivins, William P., Jr. "Texaco v. Hasbrouck: The Supreme Court Reviews Functional Discounts under the Robinson-Patman Act." Antitrust Bulletin 36 (1991): $413-55$.

${ }^{21}$ For a survey on the welfare effects of vertical antitrust legislation, see Ronald N. Lafferty, Robert H. Lande, \& John B. Kirkwood, Impact Evaluations of Federal Trade Commission Vertical Restraint Cases (1984).

${ }^{22}$ See, for example, Cable, supra note 2; Petersmann, supra note 7. 
Bonanno, Giacomo, and Vickers, John. "Vertical Separation.' Journal of Industrial Economics 36 (1988): 257-65.

Brander, James A., and Spencer, Barbara J. "Export Subsidies and International Market Share Rivalry.' Journal of International Economics 18 (1985): 83-100.

Cable, Vincent. "The New Trade Agenda: Universal Rules amid Cultural Diversity." International Affairs 72 (1996): 227-46.

Cheng, Leonard K., and Kreinin, Mordechai E. "Supplier Preferences and Dumping: An Analysis of Japanese Corporate Groups.' Southern Economics Journal 63 (1996): 51-59.

Coughlin, Anne T., and Wernerfelt, Birger. "On Credible Delegation by Oligopolists: A Discussion of Distribution Channel Management." Management Science 35 (1989): 226-39.

Fershtman, Chaim, and Judd, Kenneth L. "Equilibrium Incentives in Oligopoly." American Economic Review 77 (1987): 927-40.

Flath, David. "Vertical Integration by Means of Shareholding Interlocks.' International Journal of Industrial Organization 7 (1989): 369-80.

Flath, David. "The Keiretsu Puzzle.' Journal of the Japanese and International Economies 10 (1996): 101-21.

Iyori, Hiroshi, and Uesugi, Akinori. The Antimonopoly Laws and Policies of Japan. New York: Federal Legal Publications, 1994.

Kühn, Kai-Uwe. "Nonlinear Pricing in Vertically Related Duopolies." RAND Journal of Economics 28 (1997): 37-62.

Lafferty, Ronald N.; Lande, Robert H.; and Kirkwood, John B. Impact Evaluations of Federal Trade Commission Vertical Restraint Cases. Washington, D.C.: Federal Trade Commission, Bureau of Competition, Bureau of Economics, 1984.

Li, David D., and Li, Shan. "A Theory of Corporate Scope and Financial Structure.' Journal of Finance 51 (1996): 691-709.

Lin, Y. Joseph. “Oligopoly and Vertical Integration: Note.' American Economic Review 78 (1988): 251-54.

Maggi, Giovanni. "Strategic Trade Policies with Endogenous Mode of Competition." American Economic Review 86 (1996): 237-58.

Novshek, William. ' On the Existence of Cournot Equilibrium.' Review of Economic Studies 52 (1985): 85-98.

Perloff, Jeffrey M.; Rubinfeld, Daniel L.; and Ruud, Paul. “Antitrust Settlements and Trial Outcomes.' Review of Economics and Statistics 78 (1996): 401-9.

Perry, Martin K. "Vertical Integration: The Monopsony Case.' American Economic Review 68 (1978): 561-70.

Petersmann, Ernst-Ulrich. "International Competition Rules for Governments and for Private Business: A 'Trade Law Approach' for Linking Trade and Competition Rules in the WTO.' In Public Policy and Global Technological Integration, edited by Frederick M. Abbott and David J. Gerber. The Hague: Kluwer Law International, 1997.

Reitman, David. "Stock Options and the Strategic Use of Managerial Incentives." American Economic Review 83 (1993): 513-24.

Sklivas, Steven D. 'The Strategic Choice of Managerial Incentives.', RAND Journal of Economics 18 (1987): 452-58. 
Spencer, Barbara J., and Jones, Ronald W. "Vertical Foreclosure and International Trade Policy." Review of Economic Studies 58 (1991): 153-70.

Spencer, Barbara J., and Jones, Ronald W. "Trade and Protection in Vertically Related Markets.' Journal of International Economics 32 (1992): 31-55.

United Nations. The Role of Competition Policy in Economic Reforms in Developing or Other Countries. U.N. Document TD/B/RBP/80/Rev. 2. 1993.

Vickers, John. 'Delegation and the Theory of the Firm.' Economic Journal 95, Suppl. (1985): 138-47. 